\title{
Nicole Bingen, Claude-Enoch Virey à l'Université de Sienne (1593)
}

\section{Filippo Fassina}

\section{Q OpenEdition}

1 Journals

\section{Edizione digitale}

URL: http://journals.openedition.org/studifrancesi/9490

DOI: 10.4000/studifrancesi.9490

ISSN: 2421-5856

\section{Editore}

Rosenberg \& Sellier

\section{Edizione cartacea}

Data di pubblicazione: 1 décembre 2007

Paginazione: 644

ISSN: 0039-2944

\section{Notizia bibliografica digitale}

Filippo Fassina, «Nicole Bingen, Claude-Enoch Virey à I'Université de Sienne (1593)», Studi Francesi

[Online], 153 (LI | III) | 2007, online dal 30 novembre 2015, consultato il 14 janvier 2021. URL: http:// journals.openedition.org/studifrancesi/9490 ; DOI: https://doi.org/10.4000/studifrancesi.9490

Questo documento è stato generato automaticamente il 14 janvier 2021.

\section{(c) (i) (9)}

Studi Francesi è distribuita con Licenza Creative Commons Attribuzione - Non commerciale - Non opere derivate 4.0 Internazionale. 


\title{
Nicole Bingen, Claude-Enoch Virey à l'Université de Sienne (1593)
}

\author{
Filippo Fassina
}

NOTIZIA

NICOLE BINGEN, Claude-Enoch Virey à l'Université de Sienne (1593), «Bibliothèque

d'Humanisme et Renaissance», LXIX, 1 (2007), pp. 147-156.

1 L'A. descrive un episodio raccontato da Virey stesso nei due poemi sul suo viaggio in Italia (Vers Itineraires. Allant de France en Italie, 1592. Allant de Venise à Rome, 1593): il soggiorno a Siena e la visita alla Casa della Sapienza. La descrizione viene ripresa minuziosamente in questo lavoro e l'A. si sofferma su numerosi dettagli, offrendo uno spaccato della vita e delle consuetudini universitarie senesi di grande interesse socioculturale. 